\title{
The House of Commons Modernisation Committee: Who Needs It?
}

British Journal of Politics and International Relation (2007), vol.9, no.1, pp.138-157.

\author{
Alexandra Kelso \\ Department of Politics and International Relations, School of Social Sciences, \\ University of Southampton, Southampton, SO17 1BJ, UK. \\ a.kelso@soton.ac.uk
}

\begin{abstract}
Modernisation has been rhetorically important for the Labour government since 1997, and it found a dedicated outlet through the House of Commons Modernisation Committee. This committee has pursued a particular type of modernisation, which this article seeks to explore. It does this by focusing on three issues. First, it examines the role of the Leader of the House of Commons in the chair of the Modernisation Committee. Second, it looks at the work of the Modernisation Committee in comparison to that of the Procedure Committee. Finally, it contextualises the discussion of modernisation with reference to the distinction between efficiency reforms and effectiveness reforms, and explores what this reveals about the complexity of executive-legislative relations at Westminster, and about the course of the modernisation debate since 1997.
\end{abstract}




\section{Introduction}

New Labour came to power in 1997 committed to a modernising agenda informed by its adherence to the so-called Third Way, and its promise of renewing social democracy (Giddens 1998 and 2000; Clift 2001). The discourse of the Third Way signified a 'reconfiguration of relationships between economy and state, public and private, government and people', in which 'modernisation was a label attached to a wide-range of institutional reforms, including those of government, party and the political process itself' (Newman 2001, 40). Although there is much debate about the extent of Labour's 'newness' (Fielding 2003, 3-5), Labour's commitment to modernisation and renewal was clear. What is more doubtful is the success enjoyed by the government in securing this modernisation. This is particularly relevant with respect to the party's pledges on constitutional change and modernisation. Labour came to power with a broad set of proposals, most notably on devolution, freedom of information, human rights legislation, and the reform of parliament. However, since its election, the government has been criticised for not understanding how these reforms related to each other and impacted upon the Westminster model (Richards and Smith 2001, 164), which has resulted in the failure to reform the constitution in the way that Labour originally promised (Flinders 2004, 126).

This article seeks to examine the strand of the Labour government's modernisation programme directed towards the House of Commons. The select committee on Modernisation of the House of Commons was established within weeks of the Labour Party coming to power in 1997. Its task was 'to consider how the practices and procedures of the House should be modernised' (HC 190, 1997-98). Attempts to enhance the procedural efficacy of the chamber have a long-standing pedigree, and procedural adaptation has been most pronounced in response to government complaints about the legislative obstacle course that is the House of Commons. Procedural changes stretch back to the $19^{\text {th }}$ century, culminating in the reforms secured in 1902, which involved substantial alterations to Commons procedure in order to increase the occasions on which government business took precedence (Redlich 1908, vol. 1; Chester 1977; Borthwick 1979). Other notable moments of procedural modernisation include 1906-07 and 1945-46, when procedure committees were appointed to bring forward proposals for ensuring the expeditious dispatch of government business (Redlich 1908, vol. 2; Morrison 1964; Walkland 1979; Seaward and Silk 2004), and 1978-79, when the Procedure Committee recommended the creation of departmental select committees. 
However, the creation of the Modernisation Committee in 1997 marked a new phase in the debate over House procedure, and there are three central issues that this article will explore. First, the Modernisation Committee, although a select committee, is chaired by the Leader of the House of Commons. This role for the cabinet member who is also in charge of securing the government's legislative programme is a significant institutional innovation. Second, the Modernisation Committee has engaged with many of the issues that have in the past been the focus for the Procedure Committee, and the latter committee has, to a degree, been sidelined in the debate over procedural matters. Both these issues raise questions about who has been driving modernisation in the House of Commons and for what purposes. This leads to the third point, that in order to understand fully the nature of the Modernisation Committee and its work, it is necessary to make a distinction between 'modernisation' of the House, which is largely concerned with creating an efficient chamber, and 'reform' of the House, which is focused more upon creating an effective chamber. The distinction between these two terms has profound implications. The rhetoric and practice of modernisation since 1997 underlines the complex role of the House of Commons in terms of its relationship with the government. The modernisation project also illuminates the imbalance in executive-legislative relations at Westminster, and the ease with which government can use its position as the dominant actor at Westminster to secure changes that primarily serve its own purposes. Simultaneously, the analysis also highlights the complexity and subtlety of executive-legislative relations at Westminster, which are not necessarily a zero-sum game. The pursuit of particular kinds of efficiency reform may contribute to an increase in the effectiveness of the chamber, and viceversa. The categories are not necessarily mutually exclusive. The two different perspectives on reform are nevertheless useful indicators of how different actors perceive the role and purpose of the House of Commons.

\section{The Role of the Leader of the House}

One of the most intriguing aspects of the Modernisation Committee has been the role of the Leader of the House of Commons as its chair, the minister who is charged with securing the government's legislative agenda (see Table 1). Of particular interest is the way in which different Leaders have adapted the institutional capabilities of the office. Some have moulded their position inside the Modernisation Committee in order to secure procedural change that largely favours the executive, while others have used the position to promote change that 
favours the legislature. The emphasis of each Leader of the House has been determined by their view of the nature of executive-legislative relations at Westminster, and what the respective powers of government and parliament should be.

Table 1: Leaders of the House, 1997-2005

\section{Term of office}

Ann Taylor $\quad$ May 1997-July 1998

Margaret Beckett July 1998-June 2001

Robin Cook June 2001-March 2003

John Reid* March 2003-June 2003

Peter Hain June 2003-May 2005

Geoff Hoon May 2005-May 2006

Jack Straw May 2006-Present

* Given his short time in the job, John Reid is not discussed in terms of his modernisation focus while Leader of the House

MPs themselves have noted the innovation of having the Leader of the House chair the Modernisation Committee, and it has prompted criticism from opposition members since the establishment of the committee. Sir Patrick Cormack MP voiced early concerns about 'the essential dichotomy' that lay with the dual role of the Leader of the House in the chair of the Modernisation Committee. He noted that the Leader of the House, then Ann Taylor, was 'in her capacity as a leading Member of the Government, understandably anxious to get government business through ... but to get business through and to have it properly scrutinised ... is a problem' (Hansard, col. 936, 14 May 1997). Similarly, Sir Alistair Goodlad, former shadow Leader of the House, argued that, 'to the Government, modernisation may mean changes to the House's procedures in the interests of government' (Hansard, col.500, 4 June 1997).

Having the Leader of the House chair the Modernisation Committee is an institutional innovation, and goes against the understanding that select committees are there to scrutinise members of the government, not be chaired by one. Consequently, there was always the chance that opposition members would block the election of the Leader of the House into the 
chair. This possibility became more likely with the increasing level of frustration felt by opposition MPs at the nature of modernisation proposals. When, in 2001, the late Robin Cook replaced Margaret Beckett as Leader of the House, there were concerns that some opposition members of the committee might attempt to prevent his election to the chair, as a result of concerns about the direction of the modernisation project under Beckett (Cook 2003, 27). Such fears proved to be unfounded, as Cook was renowned for his parliamentarianism and reform instincts. In a significant display of bipartisanship, Cook was nominated for the chair by Sir Nicholas Winterton, a Conservative MP and chairman of the Procedure Committee, who shared Cook's reformist instincts.

The appointment of the Leader of the House to the chairmanship is itself testament to the generally slow pace of reform inside the Commons and to the desire of the government to ensure that particular types of change are secured more quickly. The course and focus of Commons modernisation since 1997 demonstrates the extent to which the committee's reform proposals are directly related to the needs of government. It also underlines the corresponding view that placing a cabinet minister at the helm of the Modernisation Committee would ensure that certain kinds of modernisation would be approved by the House of Commons. Ann Taylor's time in the chairmanship suggests a fairly restrictive approach to modernisation. During her year as Leader of the House, the Modernisation Committee looked at issues such as explanatory material for bills (HC 389, 1997-98), conduct in the chamber (HC 600, 1997-98) and voting methods (HC 699, 1997-98; HC 779, 1997-98). The committee also looked at expediting government business, and conducted an examination of the legislative process resulting in the initial recommendations for legislative programming (HC 190, 1997-98). Taylor also oversaw the publication of a report aimed at improving Commons scrutiny of European legislation (HC 791, 1997-98). Overall, however, Taylor's focus left many MPs unsatisfied, particularly those who adopted a more expansive view of the modernisation project. In spring 2002, a series of interviews were conducted by the author with several MPs on the Modernisation Committee, during which they were asked about their thoughts regarding the role and impact of the respective Leaders of the House. A Labour Modernisation Committee member stated that Taylor had 'lacked the political clout to really drive the agenda forward' (interview, 15 May 2002). Another Labour committee member believed that under Taylor, Commons reform had been 'tame and mere tinkering', and that its piecemeal nature had limited the impact of the changes (interview, 16 April 2002). 
Taylor herself accepted that the legislative reforms she had introduced were "not exactly earth shattering' (Hansard, col. 1065, 13 November 1997).

Margaret Beckett prioritised the interests of government well above those of the House of Commons in her approach to modernisation. Margaret Beckett was in the chair of the Modernisation Committee during its most divided periods, when it looked at sitting-hours changes (HC 60, 1998-99; HC 719, 1998-99; HC 954, 1999-2000) and at legislative programming (HC 589, 1999-2000; HC 382, 2000-01). It was not only the House that was divided by these proposals, but the committee itself, where the legislative programming proposals caused a considerable partisan divide. Beckett was also in the chair when the committee advocated sittings in Westminster Hall (HC 906, 1999-2000), aimed at providing an additional forum for the discussion of those matters that did not find adequate time on the floor of the Commons. Modernisation Committee members who were interviewed were critical of Beckett's time in the chair. They noted that under her leadership 'we made no progress whatsoever', that the whole process had been 'stalled' and that she 'was not at all convinced of the need for modernisation and nothing was achieved in her reign' (interviews, 23 April 2002, 22 May 2002, 16 April 2002, 15 May 2002). David Curry, a Conservative member of the Modernisation Committee, described Beckett's attitude towards it as 'fairly Stalinist' (Hansard, col. 688, 14 May 2002). Indeed, while Beckett was quick to point out that the Westminster Hall proposals were made by committee members themselves (Hansard, col. 82, 24 May 1999), it was clear from the various committee reports that the changes to sitting hours and the reforms to legislative programming, which provoked most controversy, were made at the behest of government. Margaret Beckett's approach to the House of Commons in general, and reform in particular, echoes that of other non-reforming Leaders of the House, such as Herbert Bowden (1964-66) and Fred Peart (1968-70).

The late Robin Cook stands in direct contrast to Margaret Beckett in terms of his focus while Leader of the House. His agreement, in 2001, to examine the select committee system is consistent with a reformist outlook, as is the committee's subsequent report (HC 224, 200102). Despite the limited success of that endeavour, the effort nevertheless places Cook on par with the other reforming Leaders of the House in recent decades, such as Richard Crossman (1966-68) and Norman St.John-Stevas (1979-81). Cook also attempted to resolve some of the problems that had plagued the modernisation project since 1997. For example, the report 
published in September 2002 (HC 1168, 2001-02) represented a mopping-up operation, particularly in terms of sitting hours and legislative programming. Although Cook adopted a generally consultative approach to modernisation, it was not always successful, and the sitting-hour changes were only narrowly approved and were later partially reversed. Nevertheless, Cook had broad, cross-party support from members of the Modernisation Committee. One member argued that the role of Cook was 'one of the key dynamics' to the modernisation process, and described Cook as 'a different kettle of fish' to his predecessors (interview, 14 May 2002). Other members believed Cook wished to be remembered by history as a big reformer (interviews, 17 and 22 April 2002), and that he had the political will to make changes to parliamentary structures (interview, 17 April 2002).

Peter Hain might usefully be located as somewhere between Robin Cook and Ann Taylor in terms of his modernisation focus. He revisited scrutiny of EU legislation (HC 465, 2004-05) and examined broader issues, such as the way in which parliament connects and communicates with the public (HC 368, 2003-04). He attempted to resolve the question of House sitting hours, and to find a compromise between the government's desire to have the House end its business earlier and the wish of a significant portion of MPs to continue sitting into the late evening (HC 88, 2004-05). Both Cook's and (to a lesser extent) Hain's generally consultative approach to these matters contrast with Beckett's. In this respect, the institutional position of Leader of the House can be adapted in quite different ways depending on the office holder, demonstrating that agents can, within clear limits, affect structure through their adaptation of the rules of the game.

Under the chairmanship of Geoff Hoon, the Modernisation Committee entered something of a fallow period. Although continuing to look at issues surrounding parliament's relationship with the public, there was only one major enquiry launched, looking at the legislative process, which did not begin until early 2006 (HC 810, 2005-06). This enquiry did, however, refocus attention away from legislative programming and towards broader issues of how the House of Commons approaches legislative scrutiny, many of which had been overlooked since the Modernisation Committee first explored such matters in its first session (HC 190, 1997-98). This enquiry continued under the chairmanship of Jack Straw, who became Leader of the House in 2006, with the final report not yet published at the time of writing. 
The preoccupation of the Modernisation Committee with sitting hours and legislative programming illustrates that the modernisation process has not only been geared towards the interests of government, but has also largely been driven by it. This is brought into further relief when the work of the Modernisation Committee since 1997 is contrasted with that of the Procedure Committee before 1997.

\section{The Circumvention of the Procedure Committee}

The Modernisation Committee has essentially usurped many of the functions of the Commons Procedure Committee. The terms of reference of both committees are remarkably similar. The Procedure Committee is instructed 'to consider the practice and procedure of the House in the conduct of public business, and to make recommendations' (HC 325, 2003-04). The Modernisation Committee is instructed 'to consider how the practice and procedures of the House should be modernised, and to make recommendations' (HC 190, 1997-98). The terms of reference of the Procedure Committee do not specifically use the term 'modernisation', but modernisation has frequently been the aim of many of its proposals since at least the 1960s. Furthermore, the Procedure Committee has previously examined many of the issues the Modernisation Committee has focused on since 1997.

For example, the Procedure Committee has examined the possibility of changing the sitting hours of the House and the parliamentary calendar on a number of occasions over the past four decades (HC 153, 1966-67; HC 356, 1967-68; HC 491, 1974-75; HC 588, 1977-78; HC 157, 1986-87). The appointment of the committee on Sittings of the House (the Jopling Committee) in the early 1990s demonstrates that the Procedure Committee's recommendations have not always been implemented (although the Jopling Committee hardly fared any better, as the House took over two years to adopt only a select few of its proposals (Seaward and Silk 2004,150)). The Procedure Committee has also examined the legislative process (HC 538, 1970-71; HC 49, 1984-85). The latter of these two reports examined the case for legislative programming, recommending that the House establish a legislative business committee to introduce timetables for bills. Both government and opposition were hostile to this proposal, because it placed power into the hands of parliamentarians rather than the usual channels. Their thwarting of this plan provoked much criticism from the committee (HC 324, 1985-86). Its approach to these and other matters has arguably been somewhat haphazard and irregular, particularly in comparison with that of the 
Modernisation Committee, which has repeatedly returned to these issues to forge a way forward. Clearly, having the Leader of the House at the helm of the Modernisation Committee has helped ensure that such matters are not abandoned in the face of House disagreement.

The Procedure Committee was also intimately involved with the establishment of the departmental select committee system in 1979 (HC 588, 1977-78). Its assessment of those committees in 1990 (HC 19, 1989-90) concluded that the system generally was working well, although the effectiveness of the committees, as defined by the Procedure Committee, has been questioned (Judge 1992). Previous Procedure Committees had been reticent about recommending the creation of departmental scrutiny committees, paralleled somewhat by the Modernisation Committee, which failed to look at this particular aspect of House functioning until Robin Cook took over in the chair in 2001. In terms of securing changes that predominantly benefit the government, such as legislative programming, the Modernisation Committee has proved a somewhat more useful vehicle than has the Procedure Committee. The position of the Leader of the House within the Modernisation Committee, particularly in terms of setting its agenda, is undoubtedly valuable. However, just as the Procedure Committee has found it difficult to overcome the partisan environment of the Commons in order to secure change, so too has the Modernisation Committee. Although the Modernisation Committee has made changing the sitting hours of the House and consolidating legislative programming its own terrain since 1997, the Procedure Committee has nevertheless become involved in both these matters when the Modernisation Committee struggled to secure consensus. It might therefore be inaccurate to say that one committee has usurped the other. The inclusion of the chairman of the Procedure Committee in the membership of the Modernisation Committee suggests more of a pooling of resources, as opposed to an institutional turf war. Nevertheless, the Procedure Committee chairman, Sir Nicholas Winterton, has persisted in expressing his concern about the Modernisation Committee's handling of a number of issues. Legislative programming has been a particular focus of his, and he has continually called for a review of its operation (Hansard, col. 463, 27 January 2005). However, the extent to which the Modernisation Committee can be viewed as a government-driven version of the Procedure Committee indicates a certain muddying of the waters in terms of House of Commons procedure. What is clear, however, is that the Modernisation Committee, dominated (as are all select committees) by MPs of the governing 
party and, crucially, chaired by a government minister, is a vastly superior tool for promoting and securing procedural modernisation than is the Procedure Committee.

\section{The Values Underpinning the Modernisation Project}

The role of the Leader of the House inside the Modernisation Committee, coupled with the evidence that the Committee has assumed pre-eminence over several important issues that had previously been the preserve of the Procedure Committee, demonstrates that government has been driving the modernisation project since 1997. However, the definition of modernisation, and its supposed purposes, has been contested. For example, Robert Jackson MP (a Conservative member until his defection to the Labour Party in January 2005) pointed to a trend of equating modernisation with the removal of antiquated practices, arguing that '[d]oing away with such things might become a compensation for a real lack of radicalism' (Hansard, col. 503, 4 June 1997). There is, therefore, uncertainty over the specific meaning of the term 'modernisation', and the extent of any 'radicalism' it might encompass.

The terms of reference of the Modernisation Committee, noted earlier, are rather vague on the aims of modernisation. The first report from the committee indicated that it had been appointed 'to consider how the practices and procedures of the House should be modernised' (HC 190, 1997-98), but did not attempt to explore the meaning of the term 'modernisation' in any detail. A subsequent report went somewhat further, indicating that the aim of modernisation was to enable 'the House and its Members to work more effectively and more efficiently' (HC 600, 1997-98, para. 1). However, the Modernisation Committee has failed to acknowledge the important distinctions to be made between these two goals of effectiveness and efficiency. It is a distinction that goes directly to the heart of the modernisation debate. Both efficiency reforms and effectiveness reforms are concerned with the nature of the relationship between the executive and the legislature. However, proponents of each take a somewhat different view of the nature of that relationship and, consequently, of the kinds of reform that are required in the House of Commons.

Efficiency reforms involve maximising the outputs of the House of Commons by using the minimum of resources. This leads to two rather different dimensions of efficiency, which neatly intertwine. First, efficiency reforms may be concerned with streamlining the workings of the Commons. This streamlining might, for example, involve changes to the sitting hours 
of the House, something that has formed the backbone of the modernisation project since 1997. This dimension of reform seeks to secure the efficient functioning of the House as a whole, and to ensure that MPs are managing available resources efficiently. Second, efficiency reforms may be designed to ensure that government business progresses through the Commons as quickly as possible. The aim is to expedite the business of government and remove any perceived undue hindrance to the progress of legislation. Since 1997, legislative programming has constituted the Modernisation Committee's main attempt to ensure that government business is secured expeditiously. These two strands of efficiency reformstreamlining and expediting - complement each other. Governments wishing to ensure that their legislative programme is approved by parliament expeditiously will also be interested in ensuring that the Commons is a streamlined chamber, and vice versa.

Proponents of effectiveness reforms, by contrast, adopt a somewhat different view of the relationship between executive and legislature. Reforms geared towards enhancing the effectiveness of the House of Commons will favour strategies that alter the institutional context within which the Commons operates, a context that is predisposed towards the goals of the executive. These reforms will aim to alter the dominant value system inside the Commons, a system that reflects an executive mentality and its preservation through partisanship (Judge 1993; Flinders 2002). The aim of effectiveness reforms is to secure a context within which the House of Commons can engage in more rigorous executive scrutiny and thus hold the government to account more fully. Such reforms may also aim to reduce the effects of partisanship in the Commons. Effectiveness reforms are therefore mainly concerned with re-balancing executive-legislative relations in favour of parliament. However, they may also seek to address the relationship between parliament and the public, given parliament's role in legitimating the actions of government. Such reforms may be geared towards improving the linkage mechanisms provided by parliament. It may therefore be useful to think of these types of reform as concerned with scrutiny effectiveness and representational effectiveness.

It is worthwhile restating that the two different kinds of reform-efficiency and effectiveness - are not necessarily mutually exclusive. Nevertheless they are useful indicators of how different individuals or groups perceive the purpose of parliament in general, and the House of Commons in particular. Those who favour effectiveness reforms may generally be 
described as favouring a more 'proactive' Commons. These reform advocates may argue that, while the Commons should not presume to usurp executive functions, it should nevertheless enjoy a greater role in scrutinising government, on account of its representative and legitimation functions. By contrast, those who favour efficiency reforms may generally be described as largely content with the current role of the House of Commons. These reform advocates may be much more interested in ensuring that governments can be assured of securing their legislative programmes expeditiously. Simultaneously, they may believe that streamlining the procedural efficiency of the House will not only be beneficial to MPs, but will also ensure the smooth operation of the Commons as a legislative machine.

At first glance, the term 'modernisation' seems to fit best with the streamlining aspect of the efficiency-type reforms, which might conceivably include updating antiquated procedures and changing the working hours of the House. However, the vague definition offered by the Modernisation Committee means it can also easily be interpreted as involving the second dimension of efficiency, relating to the expediting of government business. Tony Wright highlighted this definitional ambiguity in a Commons debate in May 2002:

When we talk about modernising Parliament, I get rather uneasy, as modernisation can mean different things. It can mean allowing the Executive to have an easier life and to get their business through in a more straightforward way, as well as tidying up some of the untidy bits of how this House operates, including things that I like, such as ensuring that we get home earlier at night (Hansard, cols 685-686, 14 May 2002).

However, a March 1998 report from the Modernisation Committee also indicated its intention to examine potential improvements to the effectiveness of the House (HC 600 1997-98; para. 1). As Tony Wright noted, efficiency improvements 'are important matters' but they do not 'go to the heart of the constitutional issue' surrounding the drift of power away from parliament and towards the executive (Hansard, cols 685-686, 14 May 2002). This does not mean that the two types of reform cannot proceed together. However, the different emphases do suggest that a desire to enhance the efficiency of the Commons might mitigate the extent to which one might also wish to improve the effectiveness of the Commons. Indeed, the extent to which the term 'modernisation' is itself synonymous with the goals of efficiency 
reforms raises questions about whether the remit of the Modernisation Committee includes the kind of effectiveness reforms outlined here.

That there is a tension between the efficiency and effectiveness dimensions of reform is evidenced in the work undertaken by the Modernisation Committee. Most of the committee's proposals have focused on the efficiency dimension of reform, with substantially less attention paid to the goal of securing a more effective House of Commons. Table 2 places each report from the Modernisation Committee under the heading of effectiveness or efficiency, respectively, as those terms have been defined here. In the absence of space to discuss each report in detail, the remainder of the article will focus on a few key examples. Exploration of the progress of sitting-hours changes and the securing of legislative programming in particular underlines how divisive these issues have been and the partisan responses that they have provoked.

Table 2: The Efficiency and Effectiveness Reports of the Modernisation Committee

\section{Efficiency reports}

Streamlining

Explanatory Material for Bills (HC 389, 1997-98)

Conduct in the Chamber (HC 600, 1997-98)

Consultation Paper on Voting Methods (HC 699, 1997-98)

Voting Methods (HC 779, 1997-98)

The Parliamentary Calendar: Initial Proposals (HC 60, 1998-99)

Sittings of the House in Westminster Hall (HC 194, 1998-99)

Thursday Sittings (HC 719, 1998-99)

Facilities for the Media (HC 408, 1999-2000)

Thursday Sittings (HC 954, 1999-2000)

Sittings in Westminster Hall (HC 906, 1999-2000)

Modernisation of the House of Commons: A Reform Programme (HC 1168, 2001 02)*

Expediting Sitting Hours (HC 88, 2004-05)

The Legislative Process (HC 190, 1997-98)

Carry-Over of Public Bills (HC 543, 1997-98)

Programming of Legislation and Timing of Votes (HC 589, 1999-2000)

Programming of Legislation (HC 382, 2000-01)

Programming of Bills (HC 1222, 2002-03)

\section{Effectiveness reports}

$\underline{\text { Scrutiny effectiveness }}$

The Scrutiny of European Business (HC 791, 1997-98)

Select Committees (HC 224, 2001-02)

Scrutiny of European Business (HC 465, 2004-05)

Representational Effectiveness

Connecting Parliament with the Public (HC 368, 2003-04)

\footnotetext{
* This report contained both streamlining and expediting aspects
} 


\section{Streamlining Procedures: Modernising House Sitting Hours}

Despite early indications during Commons debates that the parliamentary calendar and sitting hours were ideal issues with which the Modernisation Committee could engage, the topic has nevertheless provoked considerable controversy among MPs. The working hours kept by the House of Commons, and late-night sittings in particular, have long attracted criticism and calls for change. The first report on this issue (HC 60 1998-99) recommended that the House approve proposals made to the committee by the government for changes to sitting hours. These largely involved the House sitting and rising earlier on Thursdays, with associated changes to the times when standing committees met. The report noted that if these did not meet with approval, then the House could then consider the committee's own, slightly different plans. During the Commons debate on the recommendations, there was much argument regarding the role of the government in their formulation. Sir Nicholas Winterton speculated: 'is not one of the problems facing the House the fact that this is a House of Commons matter, yet we are considering Government proposals?' (Hansard, col. 1000, 16 December 1998). Another Conservative committee member, Sir George Young, added that 'any Select Committee, and particularly the Modernisation Committee, will want to develop its own agenda and not just accept the Government's' (Hansard, col. 1001, 16 December 1998). This controversy continued after the approval of the government-sponsored changes, demonstrated by the continuation of the Thursday changes on an experimental basis only (HC 719, 1998-99; HC 954, 1999-2000), and by the division over the merits of the changes both within the Modernisation Committee (Hansard, col.742, 25 October 1999) and in the House more generally (Hansard, cols 30-31, 20 November 2000).

Further sitting-hour changes were proposed in 2002, this time recommending that the House sit and rise earlier from Tuesday to Thursday (HC 1168, 2001-02). These again came under sustained criticism, with the late Eric Forth, then shadow Leader of the House, casting doubt on 'whether what the Government - thinly cloaked as the Modernisation Committee on this occasion-propose will make the House of Commons more effective in scrutinising the Government and holding them to account' (Hansard, col. 706, 29 October 2002). In this instance, the House only narrowly accepted the Thursday changes, and criticism continued to be voiced, most notably through an Early Day Motion that attracted 243 signatures (EDM 262, 2003-04). The Procedure Committee entered the fray to examine the matter, and recommended a reversion to previous hours on Tuesdays (HC 491, 2003-04), while another 
Modernisation Committee report recommended that the House should sit earlier on Thursdays, in order 'to restore [it] to a full sitting day', and to give the standing committees more scope to do their work (HC 88, 2004-05, paras 4-6). In the event, in January 2005, the Commons voted to support the recommendations of both the Procedure and Modernisation Committees, by resolving that Tuesday hours revert back to $2.30 \mathrm{pm}-10.00 \mathrm{pm}$, and that the House sit earlier on Thursdays. Some reformers bemoaned what they perceived to be a step backwards in the modernisation project, with Labour MP Helen Jackson announcing her intention to stand down at the next election on account of the changes (The Guardian,3 February 2005), although her dramatic reaction was atypical.

The debate over sitting hours highlights the difficulties the Modernisation Committee has experienced in securing consensus in a deeply partisan Commons environment, amid criticisms that it is simply implementing the government's agenda. A Conservative member of the All-Party Group for Parliamentary Reform expressed extreme scepticism about the way in which the Modernisation Committee had engaged with sitting-hours change:

I think there has been an unfortunate confusion between the very clear fact that our hours and our procedures are not in the current parliament family friendly-I think there's been a confusion between a reasonable desire to try to change that, and some of the steps which have been taken ... which actually don't necessarily make parliament that much more family friendly, do make the hours shorter, and which certainly constrains the ability of parliament to do its job (interview, 14 May 2002).

Changes to sitting hours are of benefit to both government and parliament, and this is not a zero-sum issue. However, the criticisms made by MPs suggest that alterations since 1997 have been largely geared towards creating an efficient parliament designed in the interests of government. Several Conservative and Liberal Democrat MPs who were interviewed expressed their belief that one of the main motivations behind the sitting-hour changes in 2002 was to ensure that Labour MPs would have ample time in their constituencies shoring up the Labour vote (interviews, 14 May 2002). Of course, MPs from other parties gain the same advantages from these alterations. Nevertheless, the extent of the controversy over the sitting hours changes demonstrates just how politicised and antagonistic these procedural matters are, even when there seems to be a majority in favour of change. In addition, 
government involvement in shaping the work of the Modernisation Committee also helps illuminate the political motivations behind modernisation.

\section{Expediting Government Business: Legislative Programming}

Of all the efficiency reforms proposed by the Modernisation Committee, perhaps none has provoked more criticism than has legislative programming. Programming mechanisms have been advocated by reformers on the basis that they give more structure and predictability to legislative scrutiny. The committee's first report recommended the adoption of legislative programming as a means to increase the expeditious dispatch of government business (HC 190, 1997-98, paras 57-66). The committee admitted that the issue was 'emotive and contentious', and that there would always be 'political considerations' involved in the handling of bills (paras 57-58). However, the report maintained that a way could be found between the informal usual channels and the more rigid guillotine. The concept of legislative programming certainly had precedents, most notably in a Hansard Society report on the legislative process (Hansard Society 1993) and in Procedure Committee recommendations for a business committee (HC 49, 1984-85), and it also formed part of the 1992 Jopling Committee proposals (HC 20, 1991-92). Yet, the Modernisation Committee rejected these approaches as inflexible, favouring instead the use of programme motions negotiated through the usual channels, and ultimately set by government (HC 190, 1997-98, para. 89).

Modernisation Committee proposals on legislative programming, and subsequent Commons debates on the matter, have revealed deep disagreements regarding the way that programming operates and the motives of the committee in supporting it. Although Commons debates illustrate that there was initially cautious cross-party support for the principle of programming (Hansard, 13 November 1997; 9 March 1998), the way that programming has functioned in practice has caused much of that support to seep away.

The committee's report of July 2000 (HC 589, 1999-2000), which outlined suggestions for improving and expanding legislative programming, did not enjoy unanimous support from the committee members. Conservative member Sir George Young proposed a dissenting report, which argued that the programming motions 'make it yet easier for Government to get its legislative programme through the House and, in so doing, lessen rather than encourage proper and adequate scrutiny' (HC 589, 1999-2000, dissenting report, para. 3). The report 
expressed concern that the Modernisation Committee was pursuing the goal of creating an efficient House at the expense of creating an effective House, and that legislative programming did not assist in tilting the terms of trade between parliament and executive back towards parliament (para. 3). It recommended that the House (or at least the opposition) should have more control over the programming process. The signatories to the dissenting report were all Conservative MPs, demonstrating the partisanship provoked within the Modernisation Committee with regards to legislative programming. This partisanship spilled over into the Commons debate on the report, in November 2000, which was further antagonised by a government business motion to limit the length of time available for the debate. On this point, the shadow Leader of the House, Eric Forth, declared that 'the Government, in the guise of the Modernisation Committee-for this purpose the two are identical have decided to assault the House of Commons' (Hansard, col. 173, 7 November 2000). Labour MP Gwyneth Dunwoody noted that she was 'deeply disturbed' by the extent of the changes being proposed, which would ultimately 'reduce the time available to the House to debate major matters' (col. 174).

An April 2001 report from the committee outlined further changes to improve legislative programming, and again included a dissenting report criticising the way programming operated (HC 382, 2000-01). Despite attempts in a September 2002 report to defuse the situation (HC 440, 2001-02), a report of October 2003 indicated that confrontation had nevertheless continued, but insisted that 'programming is here to stay' (HC 1222, 2002-03, para. 28). Two Conservative committee members again attached a dissenting report, which argued that, as a consequence of the programming procedure, guillotining of bills had become the norm, and consultation the exception (HC 1222, 2002-03).

The Procedure Committee stepped in to examine sitting hours when the extent of House disagreement became clear. Its report of July 2004 noted that 'considerable disquiet remained about the way the system operated and how that differed from what had been initially intended' (HC 325, 2003-04, para. 8). The Procedure Committee acknowledged that, if programming was to work, a point of consensus had to be found between quite different views of the legislative process, as highlighted in the oral evidence the committee collected. Shadow Leader of the House, Eric Forth, for example, argued that it was 'of the utmost importance for the effectiveness of the [legislative] process that it is the opposition which 
essentially has the dominant hand in determining how much time will be spent in committee' (HC 325, 2003-04, Q. 87). Labour Modernisation Committee member, Barbara Follett, by contrast, held the view that a more efficient method had to be found for securing legislation and reducing the excessive time often spent in standing committee (HC 325, 2003-04, Q. 88). In addition, although the Procedure Committee heard much support in favour of a legislative business committee, Leader of the House Peter Hain made his objections to such a proposal emphatically clear (HC 325, 2003-04, Q. 235). Despite the reservations expressed by the Procedure Committee, the Commons later approved measures to incorporate programming into permanent standing orders, although on strictly partisan lines (Hansard, cols 1380-1406, 26 October 2004).

The process of adopting legislative programming highlights the complexities of the relationship between the government and the House of Commons, and the degree of partisanship that surfaces when controversial issues such as these are promoted as being beneficial to parliament. As it is the Leader of the House who is in charge of securing the government's legislative programme, he or she also has a stake in consolidating a system of legislative programming that ensures bills emerge from the legislative process at specific, and pre-arranged times, thus restricting the scope for opposition and delay, an approach which was supported by most Labour MPs. By contrast, and not surprisingly, opposition members consistently argued, both inside the Modernisation Committee and in the chamber, that it was a fundamental duty of the Commons, through the opposition, to impose a degree of delay on bills, and that the government could not assume it should always secure its legislation with minimal interference from the House.

\section{The Effectiveness of the House of Commons: Select Committee Reform}

The Modernisation Committee has spent most of its time looking at issues of procedural efficiency, and effectiveness matters have received limited attention as a result. Only three reports have looked exclusively at enhancing Commons capabilities in terms of executive scrutiny. Two reports have examined scrutiny of European business (HC 719, 1997-98; HC $465,2004-05)$, an area that arguably requires much more attention. However, the most notable work done by the Modernisation Committee with regards to scrutiny is that concerning the select committee system. 
The 2002 attempt to reform the select committee system has been examined elsewhere (Kelso 2003), but the most salient point to note is that the Modernisation Committee was reluctant to recognise the need for alterations to the operation of the select committees. Formed in 1978, the select committee system was a significant step forward for parliamentary scrutiny and House of Commons effectiveness, but had nevertheless been a focus for reformers who argued that the system needs additional, perhaps even constant, revision. The Modernisation Committee only engaged with the issue after considerable attention had been brought to bear on the matter by other actors. The Liaison Committee was perhaps most vocal in its concerns, publishing a number of reports that highlighted the deficiencies of the select committee system in terms of scrutiny (HC 300, 1999-2000; HC 748, 1999-2000; HC 321 2000-01). The serious problems facing the select committees were further underlined following the rejection by backbenchers in July 2001 of the government's attempts to remove two select committee chairs, Donald Anderson and Gwyneth Dunwoody (Kelso 2003, 58-62). It is fortuitous that criticism of the existing system came to a head just as Robin Cook was appointed Leader of the House. His arrival in the chair of the Modernisation Committee enabled a window of opportunity to open in favour of reform (Norton 2000; Kelso 2003), and the committee's eventual proposals to reform the select committee system (HC 224, 2001-02) attempted to tackle some of the issues that were at the heart of the imbalance in executivelegislative relations, particularly those recommendations geared towards removing whip influence from select committee nominations, which had long been criticised for delimiting the scrutiny abilities of the select committees (Kelso 2003, 62-63). Given the track record of the Modernisation Committee to that point, it is likely that, without Cook in the chair, its response would have been quite different. It is not the case that other actors, such as the Liaison Committee, pre-empted the Modernisation Committee on this matter: the latter did not wish to be involved in questions of scrutiny at all, a stance reinforced under the leadership of Margaret Beckett. Without Cook leading the committee, the most radical of its recommendations would in all likelihood never have been made.

However, despite the Commons having the opportunity to engage with reform that would make a significant difference to its scrutiny capabilities, the House did not possess the political will to secure that reform. While a number of the proposals were accepted by the Commons in May 2002, such as core duties for select committees, the most important aspects of the reform package were defeated, such as those aimed at removing whip influence from the committee selection process (Kelso 2003, 62-66). Reformist arguments failed to sway 
those MPs who were persuaded by the whips that existing arrangements were best preserved (Kelso 2003, 64-66). Of course, core duties for select committees and payment for committee chairmen may contribute to enhanced scrutiny. However, these reforms were underpinned by the notion that the executive should not make decisions about who scrutinises it. So long as the whips play a central role in choosing those MPs who serve on select committees, the real effectiveness of these other reforms will be constrained. As one Liberal Democrat MP explained, if chairmen are paid while the committee selection process is still controlled by the whips, then it is possible that such positions can be used as 'sweeteners' to place compliant or sympathetic MPs on to certain committees (interview, 12 March 2002).

The episode underlines the difficulties faced by the Modernisation Committee when engaging with effectiveness reforms that attempt to alter the influence of the executive and of partisanship on the operation of the House of Commons. These difficulties necessarily raise questions about the utility of the Modernisation Committee as an agent for effective parliamentary reform, and where this leaves the committee's stated desire to improve the effectiveness of the Commons.

\section{The Marginalisation of Reform}

Table 2 demonstrates that, even through the crude measure of number of reports, much of the Modernisation Committee's time has been spent on efficiency issues. The categorisation of some modernisation issues may be debatable, perhaps none more so than the Westminster Hall sitting proposal. This was a measure promoted on the basis that it would 'enable the House to hold the government to account on a wider range of issues' (HC 194, 1998-99, para. 23). Westminster Hall sittings were geared towards offering a forum for those issues that did not always find time on the floor of the House of Commons, and in terms of the scrutiny that it was designed to facilitate, it is tempting to suggest that Westminster Hall is a clear effectiveness reform. Indeed, if the Hall enables more debate and discussion of important issues, and provides time to look at select committee reports and issues of backbench concern, then this can only result in more scrutiny, which is an obvious effectiveness gain. However, it is not only the existence of the scrutiny that is important, but also the context in which it takes place. The deliberately non-controversial institutional setting of Westminster Hall means it holds rather less attraction for MPs than the main chamber, where partisan debate can more usefully aid one's parliamentary career, thus reducing the impact of the scrutiny 
that takes place in the Hall. Effectiveness is therefore about the quality of scrutiny, not necessarily the quantity. Westminster Hall is not a scrutiny mechanism on par with the select committee system, not least on account of the lack of publicity that it receives, and it is therefore unclear whether it fulfils its original purpose of holding government to account on a wider range of issues. Thus far, Westminster Hall may simply have served to prevent further demands arising for scrutiny opportunities on the floor of the House of Commons, rendering it an inadvertent efficiency reform, rather than an effectiveness reform.

However, this article has maintained that these two categories are not mutually exclusive, and that changes can be both efficient and effective. Other reports in Table 2 do seem to fall into both categories. For example, the proposal to carry over bills from one session to the next can deliver both efficiency and effectiveness gains: the government may be more likely to introduce bills later in the session knowing they can be carried over to the next, rather than lost, and the Commons can conduct better scrutiny because the mechanism works against there being a glut of legislation at one point in the session. Explanatory material for bills also seems to fall into both categories: with the content of legislation more clearly explained, parliament may be able to deal with it more quickly and in better possession of the facts about the nature of the bills before it. However, when these are underpinned by legislative programming, it becomes clear that they tip rather more towards the efficiency classification, while still deriving effectiveness gains of some kind. Both consequently deliver far more benefits in terms of streamlining and expediting than they do for House effectiveness. More importantly, neither proposal is on par with those kinds of reforms designed to rebalance significantly executive-legislative relations at Westminster.

Pre-legislative scrutiny is another example of a reform that has potential benefits in terms of both House efficiency and House effectiveness, helping government to draft better legislation that may be more acceptable to parliament, and facilitating parliamentary scrutiny at an earlier stage of the legislative process. This was a mechanism to which the Modernisation Committee pledged its commitment early on (HC 190, 1997-98, para. 20), although no single report ever dealt exclusively with this matter. Pre-legislative scrutiny is valuable, but its introduction has not been an unqualified success. It has been described as lacking structure (Blackburn and Kennon 2003, 727), and the Liaison Committee in particular has drawn attention to several impediments to its effectiveness (HC 419, 2004-05, para. 20). The 
efficiency and effectiveness benefits of pre-legislative scrutiny are constrained by the lack of a coherent plan as to how such scrutiny should fit into the wider work of the House and its various committees, and thus contribute to rebalancing executive-legislative relations at Westminster. Indeed, it is the absence of a series of reform proposals that would cumulatively and systematically work towards such a rebalancing that means even those proposals that fall into both categories remain constrained in terms of what they can deliver by way of effectiveness gains. In 2006, the Modernisation Committee, first under the chairmanship of Geoff Hoon and then Jack Straw, resolved to examine once more the legislative process in its entirety, and to ascertain how legislative scrutiny could be better performed (HC 810, 200506). The fact that this enquiry looked at those issues already explored almost a decade before, in the very first report from the Committee (HC 190, 1997-98), is evidence of the difficulties the Committee has faced in securing reforms that can help enhance both the efficiency and the effectiveness of the House of Commons, particularly in the context of its focus on legislative programming in previous sessions.

\section{Conclusion}

The relative paucity of recommendations aimed at enhancing the effectiveness of the House of Commons, particularly in terms of its ability to scrutinise the executive, reveals much about the driving force behind the Modernisation Committee. Its focus on sitting hours and on legislative programming indicates that the committee has been primarily concerned with securing an efficient House of Commons, which is as streamlined as possible, and which facilitates the expeditious dispatch of government business, both of which have clear benefits for the party in power. Moves towards both these conditions have not always been easy, and the contradictory interpretations held by MPs regarding the best sitting-hours arrangements have, at least for the time being, resulted in something of a compromise between early and late sittings of the House. In terms of legislative programming, however, there is no question that with the Modernisation Committee returning repeatedly to the issue, the government has secured a process that bestows a greater degree of certainty on to the legislative process.

Analysis of the emphasis of the modernisation project since 1997 demonstrates that, despite serious arguments about the need for a more effective House with enhanced scrutiny capabilities, change has not always been forthcoming. Criticism of the focus of the Modernisation Committee, coupled with the relatively few recommendations made to 
enhance House effectiveness, has led to reformers calling for measures that would improve the scrutiny of the executive. By contrast, the Modernisation Committee has been viewed largely as a creature of government, particularly given that it is chaired by the Leader of the House, and has therefore pursued a modernisation agenda that is seen as benefiting government objectives rather than contributing to enhanced scrutiny of the government by the House of Commons. The nature of the sitting-hours changes, and particularly the nature of legislative programming, illustrate that the Modernisation Committee exists to shape House procedures so that they are of most benefit to the government, rather than to the Commons, not least in its task of holding the executive to account. When a window of opportunity did emerge to secure effectiveness reforms, and even with the Modernisation Committee chairman leading the charge for such reforms, the partisan, executive-dominated institutional setting in which MPs operate ensured that such reforms were constrained. In the final analysis, the government needs the Modernisation Committee far more than does the House of Commons, and can mould it to its own ends better than it ever could using the Procedure Committee. So long as modernisation continues to be synonymous with the goal of fashioning the most efficient chamber possible, then the Modernisation Committee is likely to persist as a government-driven feature of the parliamentary landscape.

\section{Bibliography}

Blackburn, R. and Kennon, A. (2003) Parliament: Functions, Practice and Procedures (London: Sweet \& Maxwell).

Borthwick, R. (1979) 'Questions and debates', in S. A. Walkland (ed.), The House of Commons in the Twentieth Century (Oxford: Clarendon Press), 476-526.

Chester, N. (1977) 'Questions in the House', in S. A. Walkland and M. Ryle (eds), The Commons in the Seventies (Glasgow: Fontana/Collins), 149-174.

Clift, B. (2001) 'New Labour's Third Way and European social democracy', in S. Ludlam and M. J. Smith (eds), New Labour in Government (Basingstoke: Macmillan), 52-72.

Cook, R. (2003) The Point of Departure (London: Simon \& Schuster Ltd).

EDM 262 (2003-04) House of Commons Sitting Arrangements (tabled by George Howarth MP).

Fielding, S. (2003) The Labour Party (Basingstoke: Palgrave). 
Flinders, M. (2002) 'Shifting the balance? Parliament, the executive and the British constitution', Political Studies, 50:1, 23-42.

Flinders, M. (2004) 'New Labour and the constitution', in S. Ludlam and M. J. Smith (eds), Governing as New Labour (Basingstoke: Palgrave), 126-143.

Giddens, A. (1998) The Third Way (Cambridge: Polity).

Giddens, A. (2000) The Third Way and Its Critics (Cambridge: Polity).

The Guardian, 'MP quits because of longer hours', 3 February 2005.

HC 19 (1989-90) The Working of the Select Committee System, Second Report from the Procedure Committee, HMSO.

HC 20 (1991-92) Report from the Select Committee on Sittings of the House, HMSO.

HC 49 (1984-85) Public Bill Procedure, Second Report from the Procedure Committee, HMSO.

HC 60 (1998-99) The Parliamentary Calendar: Initial Proposals, First Report from the Modernisation Committee, HMSO.

HC 88 (2004-05) Sitting Hours, First Report from the Modernisation Committee, HMSO.

HC 153 (1966-67) The Times of Sittings of the House, First Report from the Procedure Committee, HMSO.

HC 157 (1986-87) A Parliamentary Calendar, First Report from the Procedure Committee, HMSO.

HC 190 (1997-98) The Legislative Process, First Report from the Modernisation Committee, HMSO.

HC 194 (1998-99) Sittings of the House in Westminster Hall, Second Report from the Modernisation Committee, HMSO.

HC 224 (2001-02) Select Committees, First Report from the Modernisation Committee, HMSO.

HC 300 (1999-2000) Shifting the Balance: Select Committees and the Executive, First Report from the Liaison Committee, HMSO.

HC 321 (2000-01) Shifting the Balance: Unfinished Business, First Report from the Liaison Committee, HMSO.

HC 324 (1985-86) Allocation of Time to Government Bills in Standing Committee, Second Report from the Procedure Committee, HMSO. 
HC 325 (2003-04) Programming of Legislation, Fourth Report from the Procedure Committee, HMSO.

HC 356 (1967-68) Dates of the Session and the Financial Year, Report from the Procedure Committee, HMSO.

HC 368 (2003-04) Connecting Parliament with the Public, First Report from the Modernisation Committee, HMSO.

HC 382 (2000-01) Programming of Legislation, First Report from the Modernisation Committee, HMSO.

HC 389 (1997-98) Explanatory Material for Bills, Second Report from the Modernisation Committee, HMSO.

HC 408 (1999-2000) Facilities for the Media, First Report from the Modernisation Committee, HMSO.

HC 419 (2004-05) Annual Report for 2004, First Report from the Liaison Committee, HMSO.

HC 440 (2001-02) Modernisation of the House of Commons: A Reform Programme for Consultation, Memorandum submitted by the Leader of the House of Commons, HMSO.

HC 465 (2004-05) Scrutiny of European Business, Second Report from the Modernisation Committee, HMSO.

HC 491 (1974-75) Late Sittings, Third Report from the Procedure Committee, HMSO.

HC 491 (2003-04) Results of the Sitting Hours Questionnaire, Second Report from the Procedure Committee,HMSO.

HC 538 (1970-71) The Process of Legislation, Second Report from the Procedure Committee, HMSO.HC 543 (1997-98) Carry-Over of Public Bills, Third Report from the Modernisation Committee, HMSO.

HC 588 (1977-78) First Report from the Select Committee on Procedure, HMSO.

HC 589 (1999-2000) Programming of Legislation and Timing of Votes, Second Report from the Modernisation Committee, HMSO.

HC 600 (1997-98) Conduct in the Chamber, Fourth Report from the Modernisation Committee, HMSO.

HC 699 (1997-98) Consultation Paper on Voting Methods, Fifth Report from the Modernisation Committee, HMSO.

HC 719 (1998-99) Thursday Sittings, Third Report from the Modernisation Committee, HMSO. 
HC 748 (1999-2000) Independence or Control? Second Report from the Liaison Committee, HMSO.

HC 779 (1997-98) Voting Methods, Sixth Report from the Modernisation Committee, HMSO.

HC 791 (1997-98) The Scrutiny of European Business, Seventh Report from the Modernisation Committee, HMSO.

HC 810 (2005-06) Committee Stage of Public Bills: Consultation on Alternative Options, First Special Report from the Modernisation Committee, HMSO.

HC 906 (1999-2000) Sittings in Westminster Hall, Fourth Report from the Modernisation Committee, HMSO.

HC 954 (1999-2000) Thursday Sittings, Third Report from the Modernisation Committee, HMSO.

HC 1168 (2001-02) Modernisation of the House of Commons: A Reform Programme, Second Report from the Modernisation Committee, HMSO.

HC 1222 (2002-03) Programming of Bills, First Report from the Modernisation Committee, HMSO.

Hansard Society (1993) Making the Law: The Report of the Hansard Society Commission on the Legislative Process (London: Vacher Dod).

Judge, D. (1992) 'The "effectiveness" of the post-1979 select committee system: The verdict of the 1990 Procedure Committee', Political Quarterly, 63:1, 91-100.

Judge, D. (1993) The Parliamentary State (London: Sage).

Kelso, A. (2003) " "Where were the massed ranks of parliamentary reformers?"- "attitudinal" and "contextual" approaches to parliamentary reform', Journal of Legislative Studies, 9:1, $57-76$.

Morrison, H. (1964) Government and Parliament (London: Oxford University Press).

Newman, J. (2001) Modernising Governance (London: Sage).

Norton, P. (2000) 'Reforming parliament in the United Kingdom: the report of the Commission to Strengthen Parliament', The Journal of Legislative Studies, 6:3, 1-14.

Redlich, J. (1908) The Procedure of the House of Commons (London: Constable).

Richards, D. and Smith, M. J. (2001) 'New Labour, the constitution, and the reforming state', in S. Ludlam and M. J. Smith (eds), New Labour in Government (Basingstoke: Macmillan), $145-166$. 
Seaward, P. and Silk, P. (2004) 'The House of Commons', in V. Bogdanor (ed.), The British Constitution in the Twentieth Century (Oxford: Oxford University Press), 139-188.

Walkland, S. A. (1979) 'Government legislation in the House of Commons', in S. A.

Walkland (ed.), The House of Commons in the Twentieth Century (Oxford: Clarendon Press), 247-291. 